\title{
Emergency medicine preclerkship observerships: evaluation of a structured experience
}

\author{
Rick Penciner, MD
}

\section{ABSTRACT}

Objective: Medical students are expected to make residency and career decisions early in their undergraduate medical education. In medical school curricula, there is limited exposure to emergency medicine (EM) in the preclerkship years. The purpose of this study was to evaluate a structured EM observership program for preclerks by surveying the students' perceptions and attitudes about the program following their participation.

Methods: A structured observership program was developed and implemented at the University of Toronto Medical School in February 2007. All first- and second-year students were eligible to participate on a voluntary basis. Nine emergency department (ED) teaching sites were enlisted, with each site recruiting interested preceptors. The observership consisted of two 4-hour shifts with 1 preceptor at 1 site. Specific expectations were provided to the students at the start of the observership. A convenience sample was used for the period between Feb. 26 and Nov. 4, 2007, to conduct an anonymous online survey about the students' experience after the observership.

Results: During the study period, 82 students completed 99 observerships at 9 sites with 54 different preceptors. Of the 82 students who completed the observerships, 70 students completed the survey. Overall, all the students (70/70) found the experience to be worthwhile. Most students (68/70) viewed the preceptors as good role models. As a result of the observership, 47 of 70 students reported that their attitudes about and interest in EM had changed and most (59/70) planned on exploring other opportunities in EM (e.g., electives).

Conclusion: Structured EM observerships are viewed by medical students to be worthwhile. These observerships can change attitudes about and interest in EM and allow students to make more informed career choices.

Keywords: observership, preclerkship, medical student, emergency medicine, medical education

\author{
RÉSUMÉ
}

Objectif : On s'attend à ce que les étudiants en médecine choisissent un programme de résidence et orientent leur carrière tôt dans leurs études médicales de premier cycle. Or, ils sont peu exposés à la médecine d'urgence pendant le préexternat. Cette étude visait à évaluer un programme structuré de stages d'observation préexternat en sondant les étudiants sur leurs perceptions et leurs attitudes au sujet du programme après l'avoir suivi. Méthodes : Un programme structuré pour stages d'observation a été élaboré et offert à la faculté de médecine de I'Université de Toronto en février 2007. Tous les étudiants de première et de deuxième année pouvaient $y$ participer sur une base volontaire. Neuf services d'urgence d'hôpitaux d'enseignement ont participé, et chaque établissement devait recruter des précepteurs. Le stage d'observation consistait en 2 quarts de travail de 4 heures sous la supervision d'un précepteur par établissement. On a fait savoir aux étudiants quelles étaient les attentes au début de leur stage. On a sélectionné un échantillon de commodité pour la période comprise entre le 26 février et le 4 novembre 2007 en vue de réaliser une enquête anonyme en ligne auprès des étudiants afin de savoir quelle avait été leur expérience du stage.

Résultats : Pendant la période de l'étude, 82 étudiants ont fait 99 stages d'observation dans 9 services d'urgence, sous la supervision de 54 différents précepteurs. Parmi les 82 étudiants qui ont terminé leur stage, 70 ont rempli le sondage. Dans I'ensemble, tous les étudiants (70/70) ont trouvé que l'expérience valait la peine. La plupart des étudiants (68/70) considéraient que les précepteurs étaient de bons modèles. Après avoir fait ce stage, 47 des 70 étudiants sondés ont indiqué que leur attitude et leur intérêt à l'égard de la médecine d'urgence avaient changé et la plupart (59/70) comptaient explorer $\mathrm{d}^{\prime}$ autres possibilités dans ce domaine (p. ex., stage au choix).

Conclusion : Les étudiants en médecine considèrent que les stages d'observation structurés en médecine d'urgence sont utiles. Ces stages peuvent changer leur attitude et leur intérêt à l'égard de la médecine d'urgence et leur permettre de faire des choix de carrière plus éclairés.

From the North York General Hospital, North York, Ont.; Director, Emergency Medicine, Undergraduate Education, and Assistant Professor, Division of Emergency Medicine, Department of Family \& Community Medicine, University of Toronto, Toronto, Ont.

Submitted Jun. 5, 2008; Revised Oct. 2, 2008; Accepted Oct. 8, 2008

This article has been peer reviewed.

CJEM 2009;11(2):235-9 


\section{INTRODUCTION}

Medical students are expected to make residency and career decisions early in their undergraduate medical education. In Canada, medical students apply to residency programs through the Canadian Resident Matching Service (CaRMS) near the beginning of their final year of medical school. ${ }^{1}$ Successful applicants often demonstrate interest and commitment through completion of clinical rotations and electives in their desired residency field of interest.

In some medical school curricula, however, there may be limited exposure to emergency medicine (EM) in the preclerkship years. Emergency medicine teaching in the preclerkship years is often limited to basic life support training and teaching universal precautions. Observation in emergency departments (EDs) by first- and second-year medical students occurs infrequently. ${ }^{2}$ In Canada, only 1 medical school has a mandatory preclerkship rotation in EM. Furthermore, most EDs in Canada do not provide elective opportunities for preclerkship medical students. ${ }^{3}$ The first exposure to EM for most medical students is during their clerkship rotations, which is often too late for decisions regarding residency programs. ${ }^{3,4}$ Medical students often choose their career early in medical school. In one study, $60 \%$ of medical students reported they chose a career in family medicine before or during their first 2 years of medical school..$^{5}$

Currently, some students, through informal networking, arrange opportunities to observe or shadow emergency physicians in the ED. Although this has been very successful for most of these individuals, there have been some concerns raised by ED administrators about the presence of these observers (Dr. Anna Jarvis, University of Toronto, Toronto, Ont.: personal communication, 2006). These concerns include the need for credentialing, issues about patient confidentiality, lack of defined roles, impact on other learners in the ED, and infection prevention and control.

Medical students decide on their career choice based on many factors. Numerous studies have demonstrated the importance of role models in influencing the choice of clinical field for residency training. ${ }^{6-8}$ Another important factor identified was patient contact. ${ }^{9}$ Observerships provide opportunities for students to have contact with potential role models and patients in a clinical setting. However, Blumstein and Cone ${ }^{10}$ reported that students considering a career in EM face considerable difficulty when seeking emergency physician advisors because of a failure of EDs to make an adequate number of advisors available.

The purpose of this study was to evaluate a structured EM observership program for preclerks by surveying the students' perceptions and attitudes of the program following their participation.

\section{METHODS}

\section{Study design}

The study consisted of a survey of student satisfaction with a structured EM observership experience. The study was considered exempt from review by the North York General Hospital Research Ethics Board.

\section{Study setting and population}

A structured observership program was developed and implemented at the University of Toronto Medical School in February 2007. All first- and second-year students $(n=425)$ were eligible to participate on a voluntary basis. Nine ED teaching sites were enlisted with each site recruiting interested physician preceptors. The program was promoted to the first- and secondyear medical school class by email, class announcements and word of mouth. Details of the program were located on a central website administered by the EM undergraduate education office. Students contacted the site of their choice directly to arrange the observership. No students were refused an opportunity to participate. A convenience sample was used between the periods of Feb. 26 and Nov. 4, 2007.

\section{Study protocol}

The observership consisted of two 4-hour shifts with 1 preceptor at 1 site. Specific expectations and the code of conduct for the students were outlined on the program website (Box 1). Students were not involved in any aspects of patient care.

\section{Measurements}

The study tool, consisting of a 13-item questionnaire, was a survey developed by the author (Appendix 1). Questions for the study were developed based on personal interviews with selected student and faculty members from the EM undergraduate education committee, and a "debugging" procedure was applied to 
each question. The survey was reviewed by the EM undergraduate education committee. After each observership experience, students were sent a request by email with a link to an online survey that was developed using SurveyMonkey (available at www.surveymonkey .com). Completion of the survey was voluntary and not a condition for participation in the observership program. Follow-up email messages were sent to all students twice at 1-week intervals, reminding students to complete the survey. Email messages were sent by an administrator who was blinded to the student responses. Questionnaires did not request any student identifiers and all survey data were compiled anonymously. Students were asked to indicate how closely they agreed with the statements in the questionnaire using a 5-point Likert scale. Students were invited to include additional comments.

\section{Data analysis}

After completion of the study, data was transferred to a Microsoft Excel spreadsheet (Microsoft Corp.). The survey was analyzed with descriptive statistics.

\section{RESULTS}

Eighty-two students completed 99 observerships at 9 sites with 54 different preceptors. The survey was completed by 70 of the 82 students. Of the 70 students, 39 were in their first year and 31 were in their second year. Twenty-two of the 70 students had previously participated in EM observerships. Sixty-seven students found the process of setting up the observership easy. Overall, all 70 students found the experience to be worthwhile. Most of the students (68/70) viewed the preceptors as good role models. All 70 of

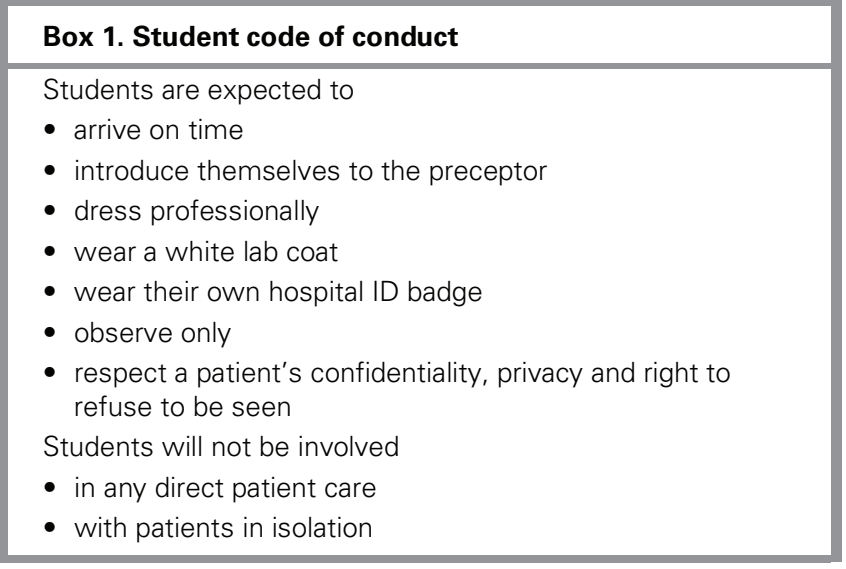

the students thought the patients accepted the students' presence as observers. As a result of the observership, 47 of the 70 students reported that their attitudes and interest in EM had changed, and 59 of the 70 planned to explore other opportunities in EM (e.g., electives). As a result of the observership, 57 of the 70 students felt they had the opportunity to contact the preceptor for further discussion (e.g., mentoring) and most students $(55 / 70)$ reported they would like to find a mentor in EM.

\section{DISCUSSION}

Clinical observerships have been used by medical students as part of their informal medical school curriculum in all disciplines, including EM. In the United States, observation in EDs by first- and second-year medical students occurs infrequently. ${ }^{2}$ In Canada, 10 medical schools incorporate some form of observership experience for preclerks (Dr. Jason Frank, University of Ottawa, Ottawa, Ont.: personal communication, June 2007). However, there is no literature describing a structured observership experience in EM and no studies on the students' experience with these observerships.

In this study, less than one-third of the students had participated in previous unstructured EM observership experiences that they themselves had arranged. Historically, there have been many barriers for students attempting to organize these experiences. For example, there has been reluctance by emergency physicians and ED administrators to take on students as observers. The ED is a high-acuity, busy clinical setting that may not be conducive to observers. Some departments and physicians receive numerous requests for observerships not only from medical students, but also from learners in other disciplines. There have been reported concerns about the credentialing of students for 1 or 2 shifts in a hospital and, since the SARS outbreak, about safety concerns regarding infection prevention and control (Dr. Anna Jarvis, University of Toronto, Toronto, Ont.: personal communication, 2006). In addition, many teaching EDs are already "overcrowded" with learners of all levels. Students may have been reluctant to arrange observer experiences because of the lack of opportunities and the complexities of arranging them. This study demonstrates that a structured experience is easy to organize and was perceived by the students to be worthwhile.

There are many potential benefits to a structured observership experience in EM. These include students' 
enhanced satisfaction with their medical education and a positive impact on career choices. Clinical experiences in the first 2 years of medical school are perceived by students and faculty to be of value. ${ }^{11}$ Preceptorships in medicine and surgery have been shown to be academically beneficial to students throughout medical school and have increased interest in those disciplines as careers. ${ }^{12}$ Medical students' career choices are strongly influenced by early exposure in medical school to specific disciplines and role models in those disciplines. Kozar and colleagues ${ }^{13}$ demonstrated that medical careers were shaped primarily by second-year preceptors. A 4-day surgical preceptorship favourably altered student perceptions of a surgical career. ${ }^{14}$ In this study, students reported that their attitudes and interest in EM changed as a result of the observership, and most reported that they would seek further opportunities in EM, such as formal electives.

Mentor relationships between faculty and students were ranked as strong influences in attracting students to specific fields of medicine. Exposure to role models in a particular clinical field is strongly associated with medical students' choice of clinical field for residency training. ${ }^{6}$ Although this observership program did not explicitly provide mentorship, it exposed students to preceptors and role models. Most students believed that their preceptor was a good role model and most reported feeling comfortable contacting their preceptor for further discussion. This study did highlight the need for mentorship of medical students in EM.

\section{Limitations}

This study has several limitations. The number of participants represented approximately $20 \%$ of the eligible medical students and may not have been representative. There was likely a selection bias in that the students participating in the program already had some interest in EM. The sample size of the study was also relatively small. In addition, the results of the survey may have been influenced by response and recall bias. Finally, the study addresses student perceptions and satisfaction. There is no clear evidence that this observership program will change outcomes such as selecting EM electives or applying to EM residencies. Future directions may include surveying the preceptor's attitudes toward supervising observers and surveying EM residents on their experiences with observership programs in medical school.

\section{CONCLUSION}

Structured EM observerships are viewed by medical students to be worthwhile. They can change attitudes about and interest in EM, and allow the students to make more informed career choices.

Acknowledgement: The author wishes to thank Nancy Medeiros for administrative support for the observership program.

Competing interests: None declared.

\section{REFERENCES}

1. CaRMS. Canadian resident matching service. 2009. Available: www.carms.ca.

2. Zun LS, Downey L. Is a third-year clerkship in emergency medicine correlated with a career choice in emergency medicine. Teach Learn Med 2004;16:14-7.

3. Frank JR, Penciner R, Upadhye S, et al. State of the nation: a profile of Canadian EM clerkships 2007. CJEM 2008;10:266.

4. Wald DA, Manthey DE, Kruus L, et al. The state of the clerkship: a survey of emergency medicine clerkship directors. Acad Emerg Med 2007;14:629-34.

5. Greer T, Carline JD. Specialty choice by medical students; recent graduate follow-up survey at the University of Washington. Fam Med 1989;21:127-31.

6. Wright S, Wong A, Newill C. The impact of role models on medical students. 7 Gen Intern Med 1997;12:53-6.

7. Burack JH, Irby DM, Carline JD, et al. A study of medical students' specialty choice pathways: trying on possible selves. Acad Med 1997;72:534-41.

8. Reed VA, Jernstedt GC, Reber ES. Understanding and improving medicals student specialty choice: a synthesis of the literature using decision theory as a reference. Teach Learn Med 2001; 13:117-29.

9. Tardiff K, Cella D, Seiferh C, et al. Selection and change of specialties by medical school graduates. J Med Educ 1986; 61:790-6.

10. Blumstein HA, Cone D. Medical student career advice related to emergency medicine. Acad Emerg Med 1998;5:69-72.

11. Johnson AK, Scott CS. Relationship between early clinical exposure and first-year students' attitudes toward medical education. Acad Med 1998;73:430-2.

12. Elnicki DM, Halbritter KA, Antonelli MA, et al. Educational and career outcomes of an internal medicine preceptorship for first-year medical students. J Gen Intern Med 1999; 14:341-6.

13. Kozar RA, Anderson KD, Escobar-Chaves SL, et al. Preclinical students: Who are surgeons? J Surg Res 2004;119:113-6.

14. Carter MB, Larson GM, Polk HC. A brief private group practice rotation changes junior medical students' perception of the surgical lifestyle. Am J Surg 2005;189:458-61.

Correspondence to: Dr. Rick Penciner, North York General Hospital, 4001 Leslie St., Rm. 1N-107, Toronto ON M2K 1E1; rick.penciner@utoronto.ca 


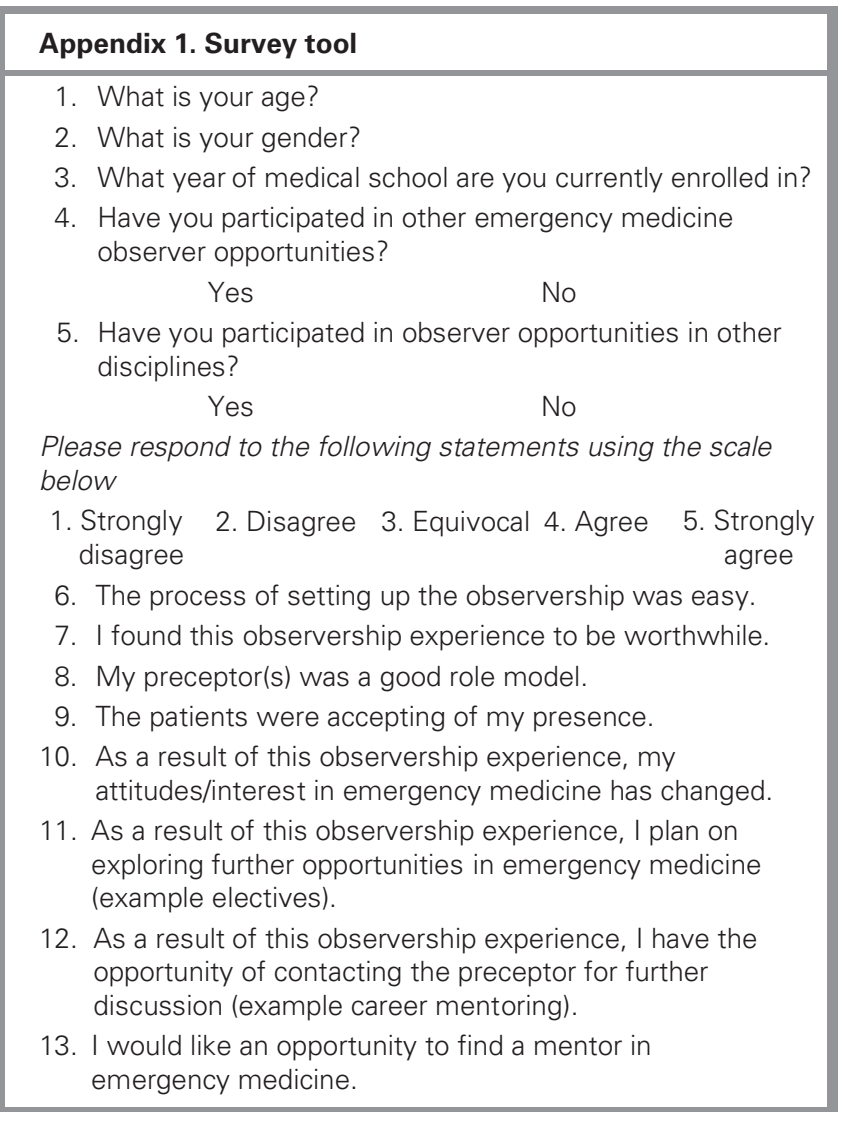

\section{Service Information}

\section{Subscription and sales}

The Canadian Journal of Emergency Medicine (CJEM) is supplied to paid-up members of the Canadian Association of Emergency Physicians (CAEP) as a perquisite of membership; others may subscribe yearly. Rates for 2009 (6 issues): Canada (personal), \$225; Canadian institutions, \$399; outside Canada (personal), US\$254; US institutions, US\$449. Contact the CAEP office (800 463-1158). Single copies of current year issues \$50; back issues $\$ 50$ (subject to availability). Payment should be made to CAEP in funds specified drawn on a Canadian or US bank. VISA and MasterCard are also accepted.

\section{Change of address}

We require 6-8 weeks' notice to ensure uninterrupted service. Please fax your current mailing label, new address and effective date to 613 523-0190 or email: cjem@caep.ca. Send US and foreign address changes to International Media Services (IMS) of New York, 100 Walnut St., \#3, PO Box 1518, Champlain NY 12919-1518.

\section{Reprints}

Bulk reprints of CJEM articles are available in minimum quantities of 50 . For information or orders, please contact the reprint coordinator, Janis Murrey, 800 663-7336 or 613 731-8610 x2110, fax 613 565-7704, janis.murrey@cma.ca.

\section{Electronic availability}

CJEM is available on the CAEP website (cjem-online.ca).

\section{Indexing}

CJEM is indexed by MEDLINE/PubMed, EMBASE, CINAHL,International Pharmaceutical Abstracts (IPA), BIOME/OMNI, Scirus, Cochrane Prehospital and Emergency Health Field, and PubsHub.com

\section{Copyright and permissions}

Copyright for all material is held by CJEM or its licensors unless otherwise indicated. You may reproduce or otherwise use material from this Journal only in accordance with Canadian copyright law and provided that credit is given to the original source. In the case of photocopying or other reprographic copying, please contact the Canadian Copyright Licensing Agency (Access Copyright): 800 893-5777; accesscopyright.ca. For any other use, including republishing, redistribution, storage in a retrieval system or transmission, in any form or by any means, please contact the CJEM Editorial Office, c/o Penelope Gray-Allan, Managing Editor, Canadian Journal of Emergency Medicine, Division of Emergency Medicine, Department of Surgery, University of British Columbia, c/o Department of Emergency Medicine, Vancouver General Hospital, 855 West 12th Ave., Vancouver BC V5Z 1M9; cjem@caep.ca

\section{Instructions for authors}

Published in the January issue of each volume. The most recent version is available online at cjem-online.ca.

\section{Advertising}

Classified ads: Contact Bev Kirkpatrick or Deborah Rodd, CJEM, 1867 Alta Vista Dr., Ottawa ON K1G 5W8; 800663 7336 or $613731-8610 \times 2127 / 2314$, fax $613565-7488$, advertising @cma.ca. See Classified Advertising section of the Journal for information on rates. Display ads: Contact Deborah Woodman (see preceding information); $\mathrm{x} 2159$. 